\title{
Assessing variability of water quality in a groundwater-fed perennial lake of Kashmir Himalayas using linear geostatistics
}

\author{
S SARAh $^{1, *}$, GH JeElani ${ }^{2}$ and Shakeel Ahmed ${ }^{1}$ \\ ${ }^{1}$ IFCGR, National Geophysical Research Institute, CSIR, Hyderabad 500 606, India. \\ ${ }^{2}$ Department of Geology and Geophysics, University of Kashmir, Srinagar 190 006, India. \\ *e-mail: geosara1@gmail.com
}

This paper presents a study on Manasbal lake, which is one of the high altitude lakes in the Kashmir Valley, India. Eighteen water samples were analysed for major ions and trace elements to assess the variability of water quality of the lake for various purposes. Geostatistics, the theory of regionalized variables, was then used to enhance the dataset and estimate some missing spatial values. Results indicated that the concentration of major ions in the water samples in winter was higher than in summer. The scatter diagrams suggested the dominance of alkaline earths over the alkali elements. Three types of water were identified in the lake that are referred to as $\mathrm{Ca}-\mathrm{HCO}_{3}, \mathrm{Mg}-\mathrm{HCO}_{3}$ and hybrid types. The lake water was found to be controlled by rock-water interaction with carbonate lithology as a dominant source of the solutes. The major $\left(\mathrm{Ca}^{2+}, \mathrm{Mg}^{2+}, \mathrm{Na}^{+}, \mathrm{K}^{+}, \mathrm{NO}_{3}\right.$ and $\mathrm{HCO}_{3}^{-}, \mathrm{CO}_{3}$ and $\left.\mathrm{Cl}\right)$ and trace elements of the lake water were within the World Health Organization standards, therefore the lake water was considered chemically safe for drinking purposes. Although $\mathrm{NO}_{3}$ concentration (ranging from 1.72 to $2 \mathrm{mg} / \mathrm{L}$ ), is within the permissible limit and not very alarming, the gradually increasing trend is not acceptable. It is however, important to guard its spatio-temporal variability as the water is used for domestic as well as agricultural purposes. This study is significant as hydrogeological information on such high altitude lakes in India is scanty.

\section{Introduction}

Lakes are inland bodies of water which are formed in rock basins of various shapes and sizes. These play an important role in the economy of a region or country and are of tremendous academic, societal and economic importance. They act as natural water reservoirs and store a large quantity of water, which can be used for drinking, industrial, irrigation, aesthetic and other purposes including generation of hydro-electricity. Kashmir is blessed with a number of lakes with different hydrological settings such as Manasbal lake (fed mainly by groundwater), Dal lake (fed mainly by fresh water streams) and Wular lake (fed mainly by the river Jhelum) (Raza et al 1978; Keller 1985; Sharma and Bakshi 1996; Kapoor and Das 1997; Hussain 1998; Khan et al 2006). The origin of the lakes in Kashmir Valley is either tectonic (as the area is tectonically active) or fluviatile, as all the lakes lie on the flood plain of river Jhelum. Our study covers one of the important lakes in India on which much hydrogeological data is not available. Moreover, studies on lakes in Kashmir are very important as information on high altitude lakes is very rare in India (Hamilton and Schaldow 1997;

Keywords. Manasbal lake; Kashmir Himalayas; chemical quality; geostatistics; major ions; trace elements. 
Subramanium 2000; Bhatt 2004). In the Kashmir Valley, tourism is the backbone of the economy and the lakes play an important role in increasing the economic status of the state. As the water quality of the lakes in Kashmir is not monitored regularly and data on the water quality of the Manasbal lake are very meagre, it is important to study the water quality of the lake and its use for various utilizations and to prevent the degradation of its quality. The purpose of this study was to assess the chemical quality of the Manasbal lake which is least influenced by anthropogenic inputs. The theory of regionalized variables was employed to augment the scarce data and has helped to improve the geochemical interpretation.

\section{Description of the study area}

Manasbal lake is the deepest ( $12 \mathrm{~m}$ deep) of all the freshwater lakes fed by groundwater in Kashmir Valley (Lawrence 1895; Raina 1971). It is situated at an altitude of $1583 \mathrm{~m}$ amsl. It lies between $34^{\circ} 15^{\prime} \mathrm{N}$ latitude and $74^{\circ} 40^{\prime} \mathrm{E}$ longitude and covers an area of about 280 ha of which 25 ha is marshy (figure 1). The lake is surrounded by moderately high mountains on its eastern and southern sides. A few limestone quarries exist towards the eastern part. The northern bank of the lake comprises a raised land or Karewas. The oblong outline of Manasbal lake extends in a NE-SW direction with a maximum length and breadth of 3.5 and $1.5 \mathrm{~km}$, respectively. The volume of water has been estimated as $12.8 \times 106 \mathrm{~m}^{3}$ Yousuf (1992). The lake is also fed seasonally by an irrigational stream; Larkul, on the eastern side, which is operational only during summer season. It drains into the river Jhelum through a $1.6 \mathrm{~km}$ Nunnyar Nalla near Sumbal village. The lake serves as an important natural water reservoir for the local population and its water is used for drinking and agricultural purposes.

\section{Geology}

The catchment of the Manasbal lake consists mainly of Triassic limestone, Quaternary karewas and Recent alluvium. Triassic limestone is made up of a thick series of compact blue limestone, slates and dolomites (Krishnan 1968; Wadia 1975). Karewas are the Lacustrine deposits of the PlioPleistocene age and are composed of fine silty clays with sand and boulder gravel (Bhat 1989). The Karewas series consists of blue, grey and bluff silts, sand, partly compacted conglomerates and embedded moraines (Wadia 1975). The alluvium consists of boulders, pebbles and sands.

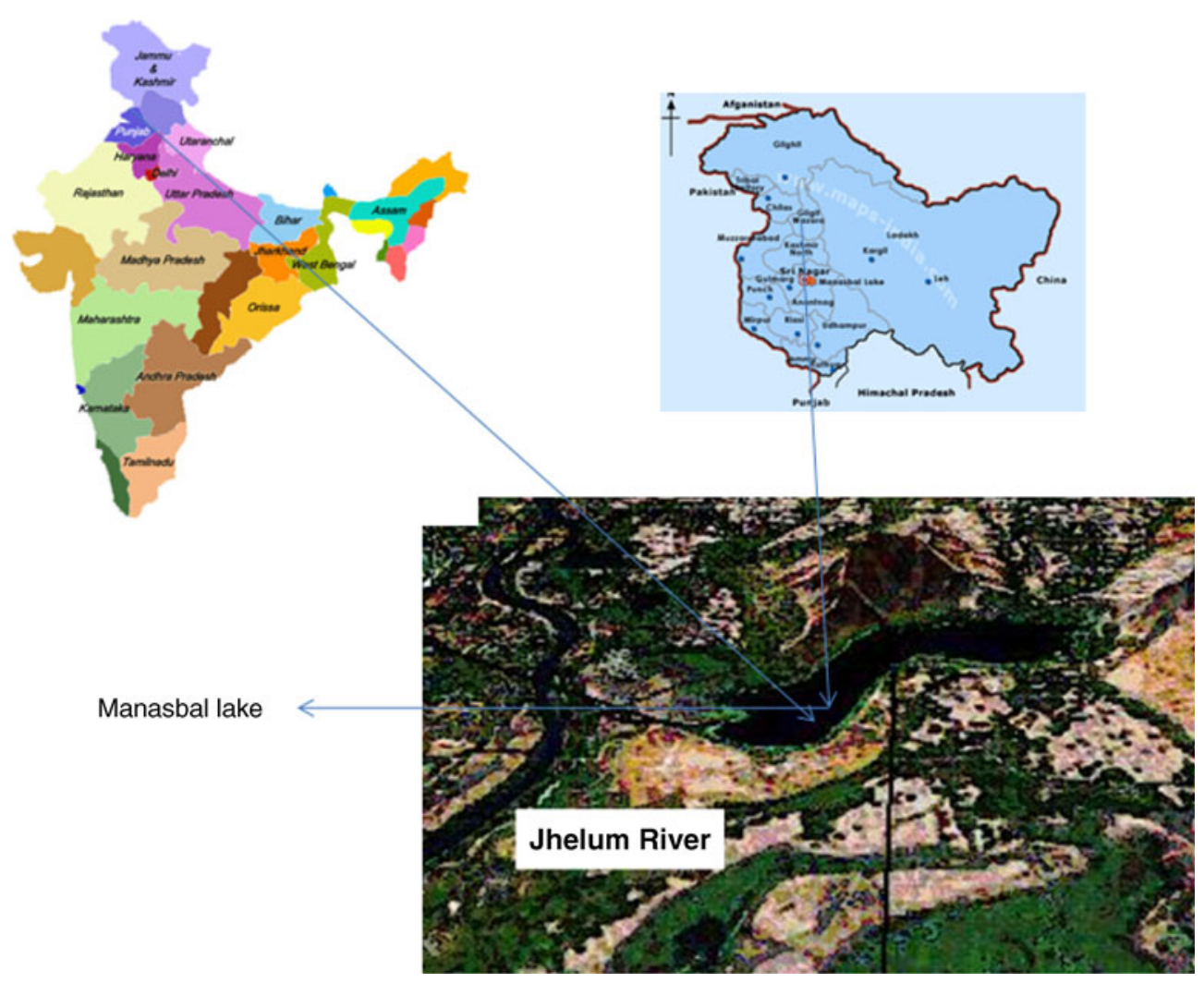

Figure 1. Location map. 


\section{Data and methodology}

\subsection{Geostatistical methods}

Data requirement is an essential but conscientious need for any study and it is very difficult to establish its sufficiency and suitability conditions. The dataset available in this study (8 measurements in summer and 10 measurements in winter) is not sufficient to perform a meaningful statistical analysis and enhancement of data population was inevitable. We have adopted a novel and special approach of using the theory of regionalized variable (Matheron 1971). We have added a matching number of additional measurement points for enhancing the dataset. However, it was not possible to obtain measured values for the same time period as in the past and hence all the water quality parameters were estimated for both the seasons using the theory of regionalized variables at new/additional points and then taken as measured/known values with the following justifications.

- The water quality of a lake that is small in dimension; about $3 \times 0.5 \mathrm{~km}$ with more or less steady flow has been studied. All the chemical constituents may be regarded as regionalized variables within the lake and theory of regionalized variables will be applied.

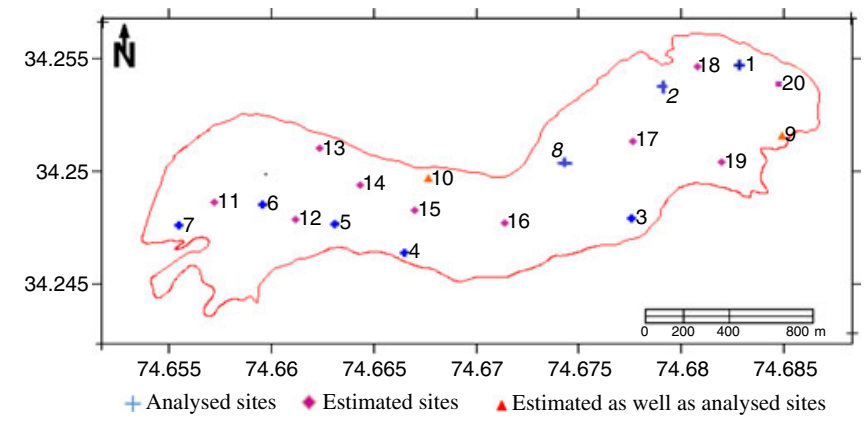

Figure 2. Sample sites (monitoring network).

- The new and additional points were taken close to the existing measurement points (figure 2) to minimize the variance of the estimation error and obtain the measured values close to the true value (Marsily and Ahmed 1987). Thus the revised dataset could consist of 20 values during June 2006 as well as 20 values during September 2006 allowing a reasonable application of graphical and statistical analyses of the water quality (Fetter 1980; Karanth 1987; Tebbutt 1998). All the observed values were first analysed for their basic statistics. Table 1 presents their minimum, maximum, variance as well as standard deviation. The basic step of applying the theory of regionalized

Table 1. Statistics of the observed values as well as the corresponding variogram parameters.

\begin{tabular}{|c|c|c|c|c|c|c|c|c|c|}
\hline & $\min$ & $\max$ & mean & var & $\mathrm{sd}$ & $\mathrm{mt}$ & $\mathrm{c} 0$ & $\mathrm{c}$ & $\mathrm{a}$ \\
\hline Tempjune & 27.9 & 29.5 & 28.8 & 0.332 & 0.576 & 2 & 0 & 0.332 & 2200 \\
\hline Tempsept & 16.4 & 17 & 16.8 & 0.0296 & 0.172 & 2 & 0 & 0.0296 & 2200 \\
\hline pHjune & 8.6 & 10.2 & 8.96 & 0.293 & 0.541 & 2 & 0 & 0.293 & 2000 \\
\hline pHsept & 7.4 & 9.2 & 8.15 & 0.255 & 0.505 & 2 & 0 & 0.255 & 1600 \\
\hline ECjune & 350 & 490 & 403 & 2290 & 47.8 & 2 & 0 & 2290 & 1600 \\
\hline ECsept & 190 & 380 & 246 & 3740 & 61.2 & 2 & 0 & 3740 & 1600 \\
\hline Cajune & 11.2 & 26.9 & 19.1 & 35.9 & 5.99 & 2 & 0 & 35.9 & 1600 \\
\hline Casept & 18.9 & 31 & 23.4 & 17.5 & 4.19 & 2 & 0 & 17.5 & 1600 \\
\hline Mgjune & 11.3 & 15.5 & 13.8 & 1.75 & 1.32 & 2 & 0 & 1.75 & 800 \\
\hline Mgsept & 12.9 & 18.1 & 15.3 & 2.68 & 1.64 & 2 & 0 & 2.68 & 2400 \\
\hline Najune & 5.68 & 9.69 & 7.49 & 2.14 & 1.46 & 2 & 0 & 2.14 & 2000 \\
\hline Nasept & 7.63 & 18.1 & 10.2 & 9.06 & 3.01 & 2 & 0 & 9.06 & 2800 \\
\hline Kjune & 0.571 & 1.98 & 1.62 & 0.195 & 0.442 & 2 & 0 & 0.195 & 400 \\
\hline Ksept & 0.769 & 1.71 & 1.38 & 0.37 & 6.88 & 2 & 0 & 0.37 & 400 \\
\hline $\mathrm{NO}_{3}$ june & 46.3 & 124 & 92.2 & 614 & 20.8 & 2 & 0 & 614 & 2000 \\
\hline $\mathrm{NO}_{3}$ sept & 14.5 & 394 & 157 & 20100 & 142 & 2 & 0 & 20100 & 2000 \\
\hline $\mathrm{HCO}_{3}$ june & 40 & 200 & 104 & 3170 & 56.3 & 2 & 0 & 3170 & 2000 \\
\hline $\mathrm{HCO}_{3}$ sept & 20 & 290 & 169 & 5470 & 74 & 2 & 0 & 5470 & 2800 \\
\hline Cljune & 2.13 & 4.97 & 3.46 & 0.934 & 0.967 & 2 & 0 & 0.934 & 2000 \\
\hline Clsept & 2.13 & 6.39 & 3.67 & 1.67 & 1.29 & 2 & 0 & 1.67 & 2000 \\
\hline $\mathrm{SO}_{4}$ june & 71.7 & 342 & 228 & 6590 & 81.2 & 2 & 0 & 6590 & 2000 \\
\hline $\mathrm{SO}_{4}$ sept & 5.05 & 372 & 222 & 17100 & 131 & 2 & 0 & 17100 & 2800 \\
\hline $\mathrm{CO}_{3}$ june & 20 & 120 & 76 & 1180 & 34.4 & 2 & 0 & 1180 & 1600 \\
\hline $\mathrm{CO}_{3}$ sept & 60 & 80 & 73.3 & 88.9 & 9.43 & 2 & 0 & 88.9 & 2800 \\
\hline
\end{tabular}


(a)

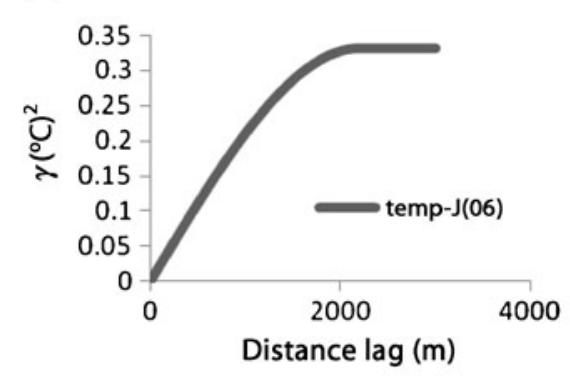

(c)

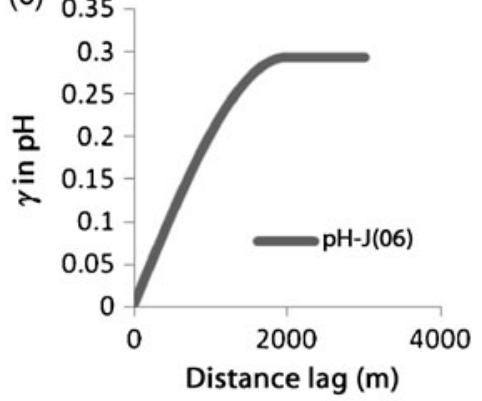

(e)
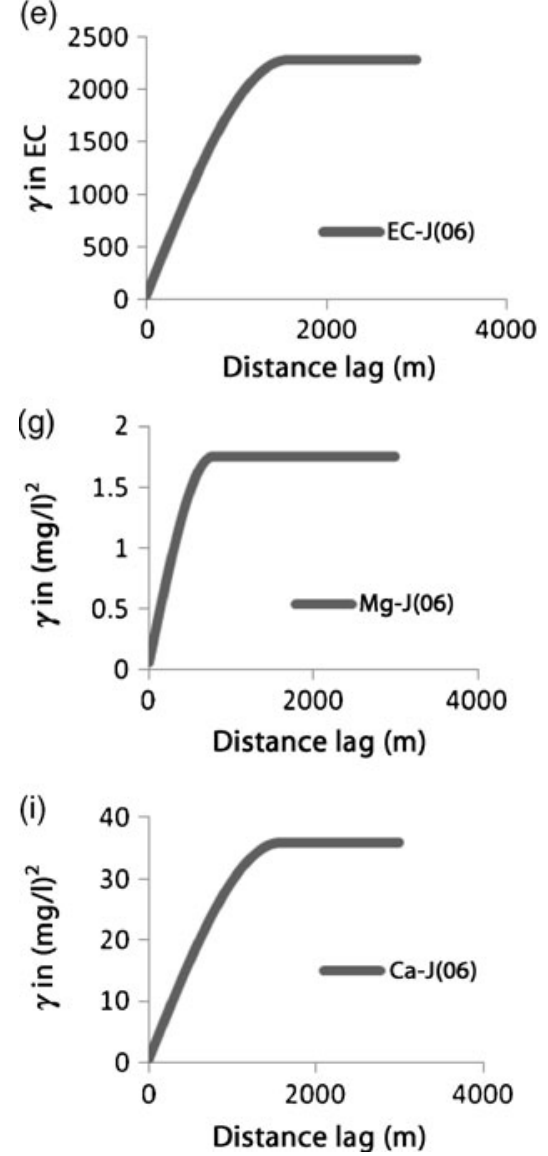
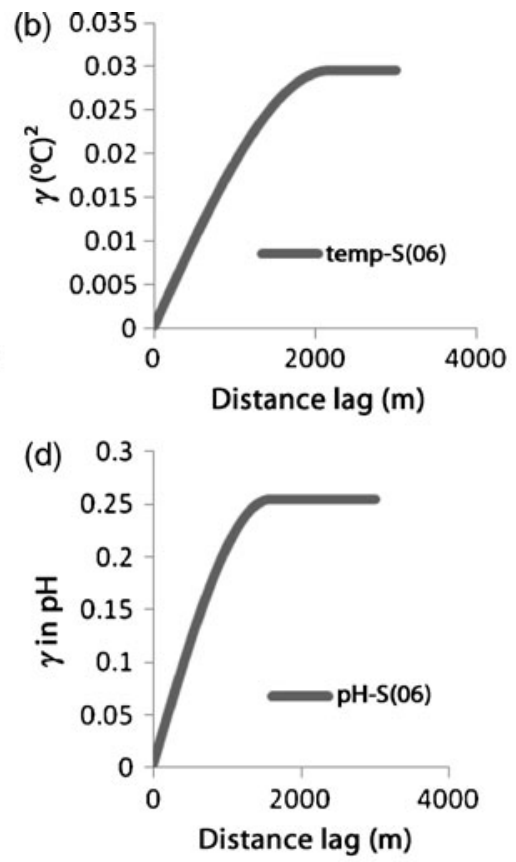

(f)
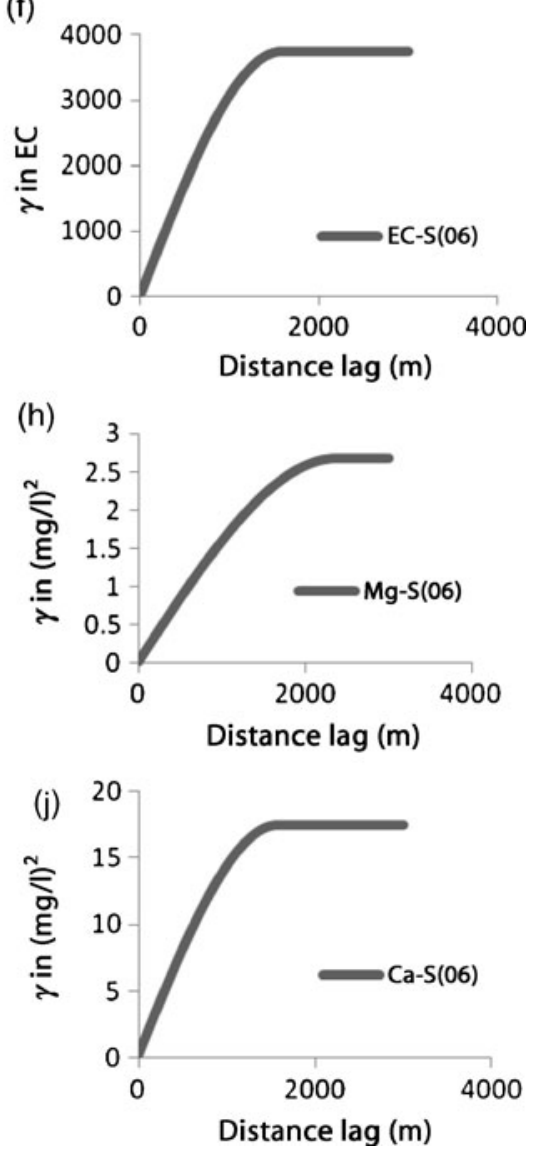

Figure 3. (a-x) Finalised variograms.

variables (i.e., geostatistics) is the estimation of experimental variograms from the measured values and their modelling using theoretical variograms. The extremely small dataset has restricted the calculation of a meaningful variogram and modelling them with unambiguous theoretical variograms. To overcome this difficulty, we have taken the aid of the crossvalidation test (Ahmed and Gupta 1989). Following assumptions were made to generate initial variograms to perform the crossvalidation tests. 

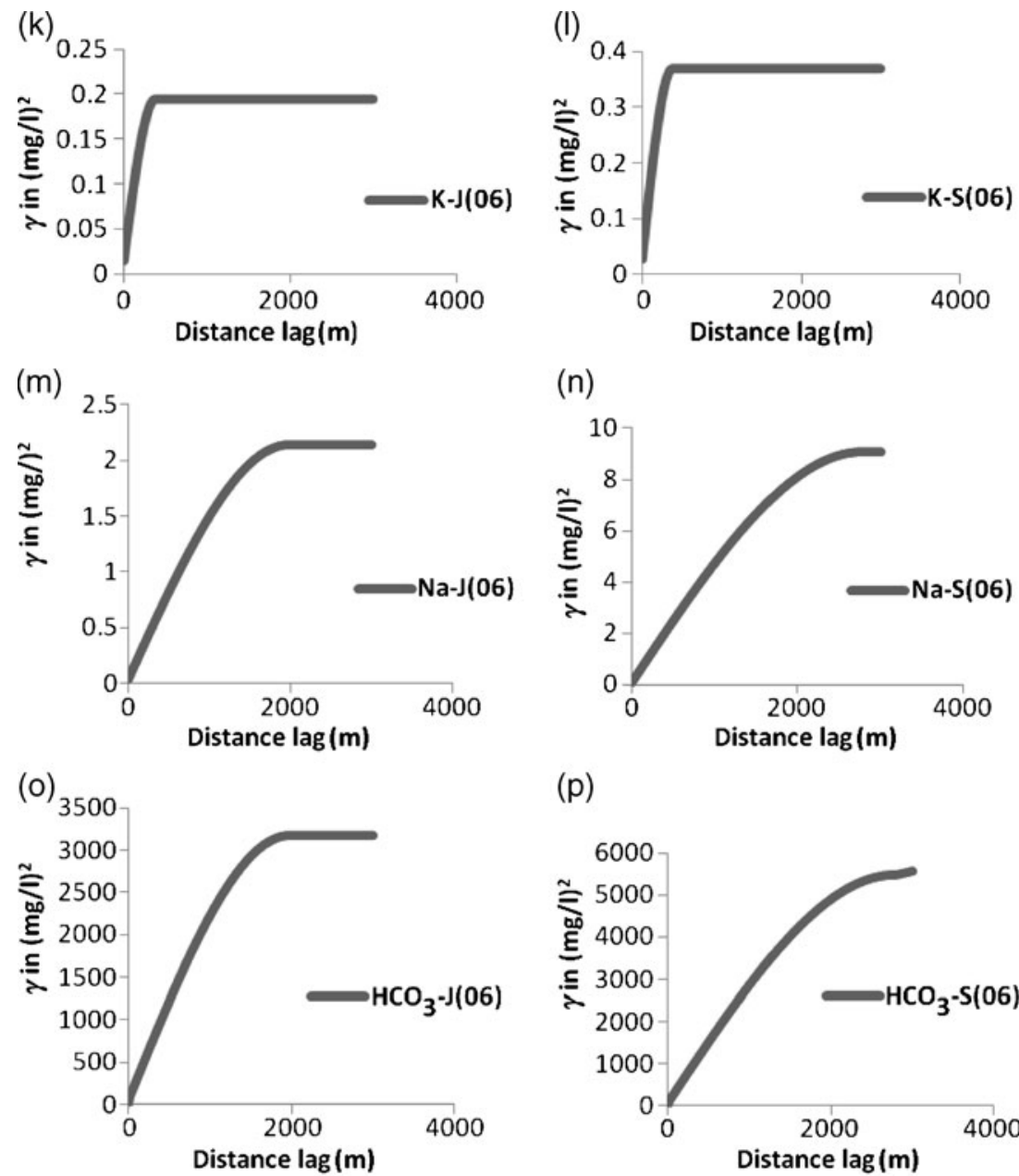

(p)
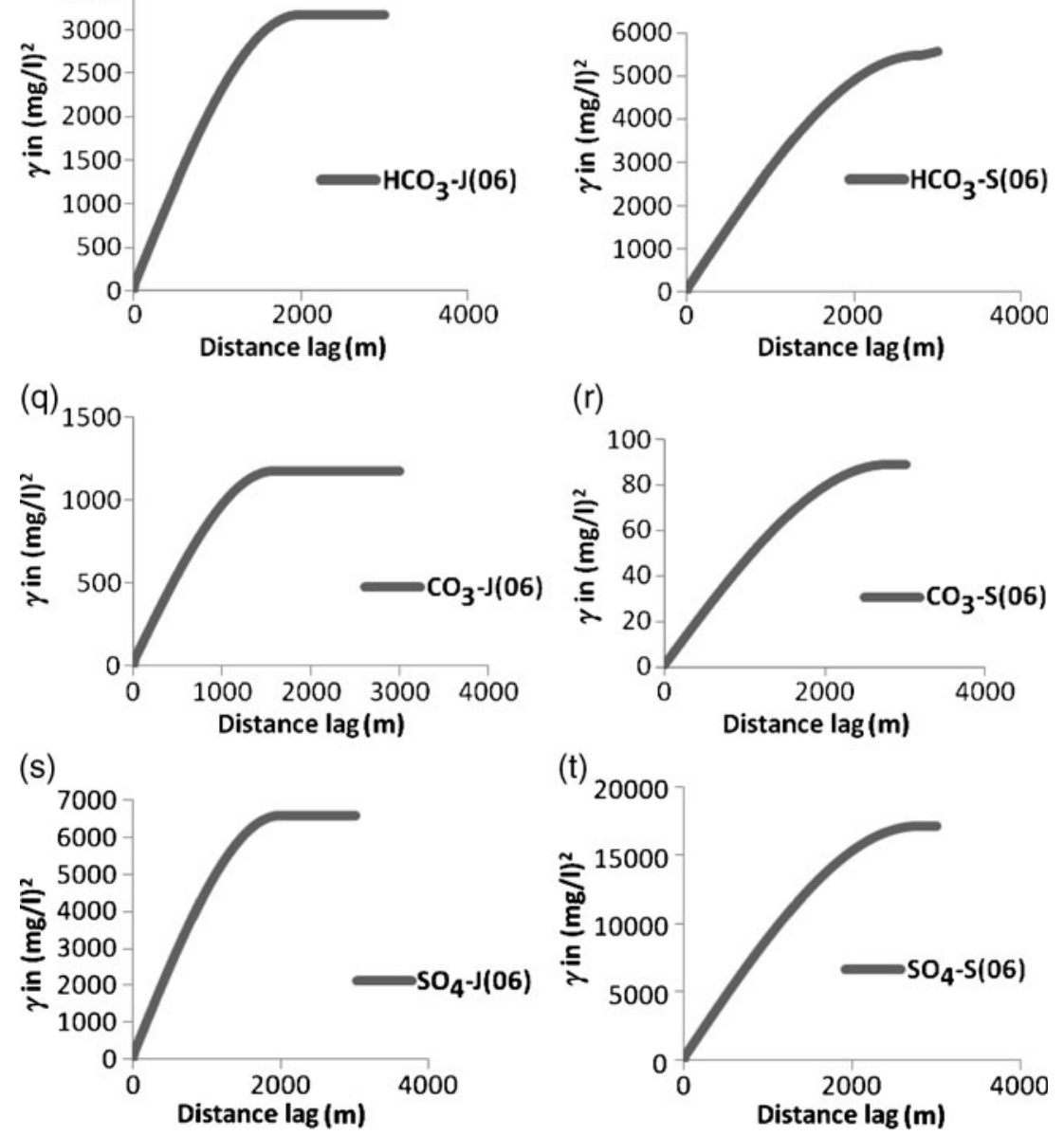

Figure 3. (Continued).

- The parameters under study, i.e., the small area of the lake and the chemical constituents determining the water quality of the lake and it was assumed that there may not be any small-scale variability and the random part may be neglected taking the values of nugget effect as zero (de Marsily and Ahmed 1987) for all the parameters. 

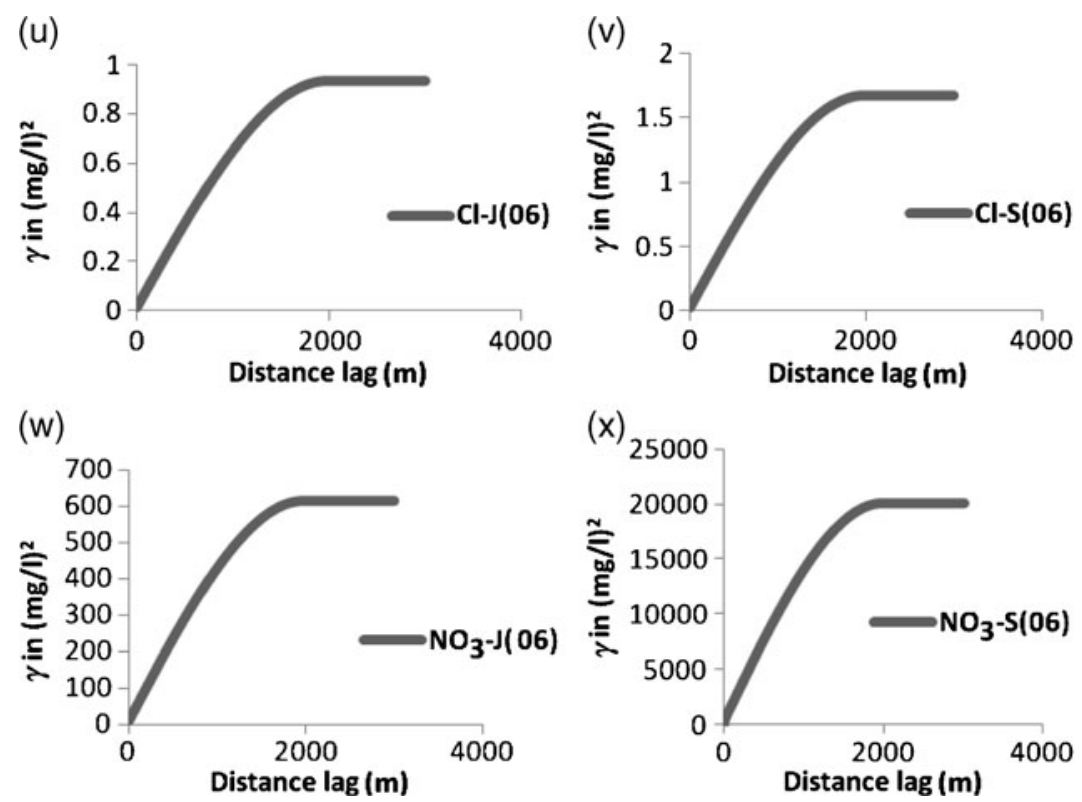

Figure 3. (Continued).

- The sill value is usually close to the variance of the parameter and hence the respective variances of the water quality parameters were taken as the corresponding sill values $(c)$.

- For simplicity and as applicable in most cases, the model type of the variogram was taken as spherical.

- The range initially varied from the least to the maximum distance possible in the lake and was finalized based on the least square difference procedure called jack-knifing.

Thus all the possible components of the variogram/ structures, viz., trend, correlation as well as noise were estimated. The cross-validation tests were performed systematically on all the parameters and suitable variograms that have satisfied the norms given by earlier studies (e.g., Ahmed and Gupta 1989) were completed. The finalized variograms of the parameters are shown in figure $(3 \mathrm{a}-\mathrm{x})$ and table 1. Finally, all the additional measurement points for the two seasons were estimated using respective variograms and the corresponding datasets using ordinary kriging (Journal and Huijbirgts 1978). As stated above, the estimated values have been taken as measured values as the variance of the estimation error obtained was low. Thus an integrated data set was prepared for further analysis and interpretation (table 2) including correlation matrix preparation. As indicated, figure 2 contains three types of data supports: 8 sites represented by $(+)$, where measurements were made for both the seasons; 10 sites represented by $(\boldsymbol{\vee})$, where values were estimated for both the seasons; and 2 sites represented by $(\boldsymbol{\Delta})$, where values were estimated only for June 2006, but were available for September 2006.

\subsection{Analytical methods}

Eighteen water samples from the lake were collected in summer and winter seasons of 2006 across the Manasbal lake (figure 2), in pre-cleaned (acid washed) HDPE bottles (Scalf et al 1987). Water samples were filtered with $45 \mu \mathrm{m}$ filters and collected in two sets. One set was immediately acidified with concentrated $\mathrm{HCl}$ and ultrapure $\mathrm{HNO}_{3}$. All the chemical constituents were analysed following standard methods (APHA 1995). Temperature, electrical conductivity (EC) and $\mathrm{pH}$ were measured in situ using a potable water analysis kit. Alkalinity was determined by acid titration with $0.1 \mathrm{~N}$ $\mathrm{HCl}$. Chloride was determined by acid titration with $\mathrm{AgNO}_{3}$. Major cations, trace and ultra-trace elements were determined by ICP-MS on the acidified set of samples. Spectrophotometry was used to determine concentration of $\mathrm{SO}_{4}$ and $\mathrm{NO}_{3}$. The normalized inorganic charge balance $\left(\mathrm{NICB}=\left(\mathrm{TZ}_{+}\right.\right.$ $\left.-\mathrm{TZ}-) / \mathrm{TZ}_{+}+\mathrm{TZ}-\right)$ ) was used to estimate overall analytical uncertainty and it should be close to zero. NICB is within \pm 0.5 .

\section{Results and discussions}

\subsection{Physico-chemical characteristics of the lake water}

The results of physico-chemical analyses of the Manasbal lake water samples collected in summer 
Table 2. Physico-chemical analysis.

\begin{tabular}{|c|c|c|c|c|c|c|c|c|c|c|c|c|c|}
\hline Sl. no. & Temp & $\mathrm{pH}$ & $\mathrm{EC}$ & TDS & $\begin{array}{c}\mathrm{Ca} \\
(\mathrm{mg} / \mathrm{L})\end{array}$ & $\begin{array}{c}\mathrm{Mg} \\
(\mathrm{mg} / \mathrm{L})\end{array}$ & $\begin{array}{c}\mathrm{Na} \\
(\mathrm{mg} / \mathrm{L})\end{array}$ & $\begin{array}{c}\mathrm{K} \\
(\mathrm{mg} / \mathrm{L})\end{array}$ & $\begin{array}{c}\mathrm{NO}_{3} \\
(\mathrm{mg} / \mathrm{L})\end{array}$ & $\begin{array}{c}\mathrm{Cl} \\
(\mathrm{mg} / \mathrm{L})\end{array}$ & $\begin{array}{c}\mathrm{SO}_{4} \\
(\mathrm{mg} / \mathrm{L})\end{array}$ & $\begin{array}{c}\mathrm{CO}_{3} \\
(\mathrm{mg} / \mathrm{L})\end{array}$ & $\begin{array}{c}\mathrm{HCO}_{3} \\
(\mathrm{mg} / \mathrm{L})\end{array}$ \\
\hline 1. $(\mathrm{J})$ & 28 & 8.6 & 471 & 301 & 23.5 & 11.3 & 6.7 & 1.4 & 0.007 & 2.13 & 0.317 & 120 & 40 \\
\hline 2. $(\mathrm{J})$ & 28 & 8.6 & 350 & 224 & 21.9 & 15.2 & 9.6 & 1.9 & 0.009 & 3.55 & 0.216 & 80 & 60 \\
\hline 3. $(\mathrm{J})$ & 27 & 9.4 & 490 & 314 & 11.2 & 13.9 & 5.9 & 1.6 & 0.005 & 4.97 & 0.168 & 60 & 70 \\
\hline 4. $(\mathrm{J})$ & 29 & 10 & 370 & 237 & 13.4 & 13.7 & 8 & 1.9 & 0.008 & 4.26 & 0.341 & 0 & 150 \\
\hline 5. $(\mathrm{J})$ & 28 & 8.7 & 380 & 243 & 26.8 & 14.8 & 5.7 & 1.8 & 0.006 & 2.86 & 0.189 & 100 & 80 \\
\hline 6. $(\mathrm{J})$ & 29 & 8.8 & 370 & 237 & 15.7 & 15.5 & 9.7 & 1.9 & 0.009 & 3.55 & 0.071 & 0 & 170 \\
\hline 7. $(\mathrm{J})$ & 29 & 8.7 & 380 & 243 & 13.3 & 12.7 & 7.7 & 1.8 & 0.008 & 4.26 & 0.257 & 0 & 200 \\
\hline 8. $(\mathrm{J})$ & 29 & 8.7 & 410 & 262 & 26.9 & 13.6 & 6.5 & 0.6 & 0.007 & 2.13 & 0.263 & 20 & 60 \\
\hline 9. $(\mathrm{J})$ & 27 & 8.9 & 471 & 301 & 18.9 & 9.6 & 6.3 & 3.2 & 0.9 & 2.91 & 0.279 & 112 & 49 \\
\hline 10. (J) & 29 & 9.4 & 375 & 240 & 18 & 6.23 & 7.1 & 3.5 & 0.06 & 3.3 & 0.281 & 28 & 109 \\
\hline 11. (J) & 28 & 8.7 & 376 & 241 & 14.4 & 13.5 & 8.7 & 3.5 & 0.09 & 3.97 & 0.173 & 0.464 & 187 \\
\hline 12. (J) & 28 & 8.7 & 372 & 238 & 21.3 & 15.6 & 7.5 & 3.7 & 0.08 & 3.19 & 0.141 & 52 & 124 \\
\hline 13. (J) & 28 & 8.6 & 376 & 241 & 25.5 & 13.1 & 6.5 & 3.7 & 0.07 & 2.73 & 0.192 & 75 & 85 \\
\hline 14. (J) & 28 & 9.2 & 375 & 240 & 21.8 & 8.1 & 6.7 & 3.9 & 0.07 & 3.28 & 0.256 & 56 & 104 \\
\hline 15. (J) & 29 & 9.5 & 377 & 241 & 20 & 5.7 & 7.1 & 3.6 & 0.08 & 3.37 & 0.284 & 33 & 110 \\
\hline 16. $(\mathrm{J})$ & 29 & 9.7 & 383 & 245 & 18.7 & 4.3 & 7.3 & 3.6 & 0.08 & 3.54 & 0.302 & 17 & 116 \\
\hline 17. (J) & 28 & 8.9 & 419 & 268 & 19.8 & 14.8 & 7.2 & 2.6 & 0.09 & 3.56 & 0.216 & 52 & 61 \\
\hline 18. (J) & 28 & 8.7 & 427 & 273 & 21.6 & 12.7 & 9.4 & 2.8 & 0.07 & 4.01 & 0.189 & 102 & 71 \\
\hline 19. (J) & 28 & 8.9 & 459 & 294 & 18.7 & 11.8 & 8.2 & 3.2 & 0.08 & 4.43 & 0.186 & 101 & 65 \\
\hline 20. (J) & 28 & 8.8 & 472 & 302 & 20.5 & 10.5 & 8.3 & 3.2 & 0.07 & 4.29 & 0.187 & 115 & 65 \\
\hline 1. $(\mathrm{S})$ & 17 & 7.7 & 340 & 217 & 29.7 & 17.3 & 18 & 1.1 & 0.02 & 4.97 & 0.005 & 0 & 200 \\
\hline 2. (S) & 16 & 9.2 & 200 & 128 & 18.9 & 14 & 9.6 & 1.4 & 0.009 & 2.84 & 0.329 & 80 & 20 \\
\hline 3. $(\mathrm{S})$ & 16 & 8.2 & 260 & 166 & 20.7 & 14.2 & 9.6 & 1.5 & 0.009 & 3.55 & 0.371 & 0 & 190 \\
\hline 4. $(\mathrm{S})$ & 16 & 8 & 230 & 147 & 21.7 & 14.5 & 7.6 & 1.5 & 0.008 & 2.13 & 0.311 & 0 & 220 \\
\hline 5. (S) & 16 & 7.9 & 200 & 128 & 19 & 12.9 & 8 & 1.3 & 0.008 & 4.97 & 0.085 & 0 & 180 \\
\hline 6. (S) & 16 & 8.5 & 190 & 121 & 20.4 & 14.7 & 7.6 & 1.4 & 0.008 & 3.55 & 0.132 & 60 & 160 \\
\hline 7. (S) & 16 & 8 & 220 & 141 & 21.1 & 14.7 & 9.7 & 1.5 & 0.009 & 2.84 & 0.3 & 0 & 160 \\
\hline 8. (S) & 16 & 7.4 & 240 & 153 & 26.9 & 18.1 & 12 & 1.7 & 0.01 & 2.13 & 0.278 & 80 & 60 \\
\hline 9. (S) & 16 & 8.7 & 200 & 128 & 24.9 & 15.7 & 11 & 1.7 & 0.01 & 2.84 & 0.051 & 0 & 210 \\
\hline 10. (S) & 17 & 7.7 & 380 & 243 & 30.9 & 17.4 & 8.4 & 0.8 & 0.008 & 6.39 & 0.352 & 0 & 290 \\
\hline 11. (S) & 16 & 8.3 & 201 & 128 & 20.4 & 14.4 & 8.7 & 2.7 & 0.02 & 3.15 & 0.222 & 27 & 159 \\
\hline 12. (S) & 16 & 8.2 & 191 & 122 & 19.4 & 13.7 & 7.8 & 2.6 & 0.04 & 4.21 & 0.114 & 26 & 169 \\
\hline 13. (S) & 16 & 7.9 & 253 & 162 & 23.3 & 14.7 & 8.5 & 2.6 & 0.3 & 5.47 & 0.154 & 17 & 191 \\
\hline 14. (S) & 16 & 7.9 & 271 & 173 & 23.8 & 14.8 & 7.9 & 2.6 & 0 & 4.96 & 0.227 & 0 & 230 \\
\hline 15. (S) & 16 & 7.9 & 342 & 219 & 28.5 & 16.5 & 8.2 & 2.6 & 0.002 & 5.63 & 0.322 & 0 & 272 \\
\hline 16. (S) & 16 & 7.8 & 322 & 206 & 27.7 & 16.6 & 8.5 & 2.6 & 0.4 & 4.53 & 0.342 & 6 & 249 \\
\hline 17. (S) & 16 & 8.3 & 232 & 148 & 22 & 15.5 & 11 & 2.3 & 1.7 & 0 & 0.335 & 53 & 88 \\
\hline 18. (S) & 16 & 8.4 & 275 & 176 & 24.5 & 13.6 & 14 & 2.9 & 2 & 0 & 0.161 & 30 & 130 \\
\hline 19. (S) & 16 & 8.4 & 260 & 166 & 24 & 13.4 & 13 & 2.8 & 1.7 & 0 & 0.166 & 10 & 171 \\
\hline 20. (S) & 16 & 8.2 & 266 & 170 & 26.5 & 13.4 & 14 & 3.1 & 2 & 0 & 0.057 & 0.417 & 201 \\
\hline
\end{tabular}

and winter seasons of 2006 are presented in table 2 . The lake water is characterized by medium to high alkalinity ( $\mathrm{pH}$ : 7.7-10), medium electrical conductivity (EC: $191-490 \mu \mathrm{S} / \mathrm{cm}$ ) and medium total dissolved salts (TDS: $122-314 \mathrm{mg} / \mathrm{L}$ ). Ca, $\mathrm{Mg}$ and $\mathrm{Na}$ are the most abundant cations with the concentrations ranging from 11.2-29.7, 4.3-18.1 and $5.7-18 \mathrm{mg} / \mathrm{L}$, respectively. Potassium is the least abundant major cation with an average value of $2.36 \mathrm{mg} / \mathrm{L}$. Bicarbonate is the most dominant anion with an average value of 20 $230 \mathrm{mg} / \mathrm{L}$ followed by $\mathrm{Cl}$ with an average value of $3.36 \mathrm{mg} / \mathrm{L}$. The concentration of sulphate and nitrate ranges from $0.005-0.371$ to $0.018-$ $2.014 \mathrm{mg} / \mathrm{L}$, respectively. All the major ions show obvious spatial variations (figure $2 \mathrm{a}-\mathrm{x}$ ). $\mathrm{Ca}$ is the dominant cation, which contributes $46 \%$ to the major cation budget while $\mathrm{HCO}_{3}$ is the dominant anion contributing $76 \%$ to the major anion budget. Thus the lake water composition is dominated by $\mathrm{Ca}$ and $\mathrm{HCO}_{3}$ ions. In general, most of the major ions $\left(\mathrm{Ca}^{2+}, \mathrm{Mg}^{2+}, \mathrm{Na}^{+}, \mathrm{K}^{+}, \mathrm{NO}_{3}\right.$ and $\mathrm{HCO}_{3}^{-}$) show higher concentration in winter and lower concentration in summer, while $\mathrm{CO}_{3}$ and $\mathrm{Cl}$ 
show lower concentration in winter and higher concentration in summer with $\mathrm{Ca}$ as a dominant cation.

\subsection{Trace and ultra-trace element chemistry}

There are some trace elements which are considered important for the human metabolism within the WHO limits and a few are carcinogenic. The concentration of all the trace elements in the lake water are within the permissible limits of WHO standards (1998). Details of the trace and ultra-trace elements of the lake water samples are given in table 3 . The concentration of $\mathrm{Fe}^{2+}(0.48-0.16 \mathrm{mg} / \mathrm{L}), \mathrm{Mn}^{2+}(0.001-0.036 \mathrm{mg} / \mathrm{L})$,
$\mathrm{Ba}^{2+}(0.008-0.029 \mathrm{mg} / \mathrm{L})$ and $\mathrm{Sr}^{2+}(0.24-0.39 \mathrm{mg} /$ $\mathrm{L})$ among the trace elements is higher in the lake water and also exhibit temporal variations, in contrast to the low $\mathrm{Al}^{2+}(0.003-0.208 \mathrm{mg} / \mathrm{L})$ concentration in the lake water. The trace elements are important for both human and plant health as well. Trace elements such as $\mathrm{Mn}, \mathrm{Fe}, \mathrm{Zn}$ and $\mathrm{Cu}$ are vital to plant metabolism as they play an essential function in processes such as respiration and photosynthesis. In humans, trace elements play a vital role in metabolic processes such as activation of enzymes, glucose metabolism, red blood cell formation, normal growth and development of body and immune system, etc. (Berner and Berner 1987).

Table 3. Trace elements.

\begin{tabular}{|c|c|c|c|c|c|c|c|c|}
\hline Sl. no. & $\mathrm{Cu}$ & $\mathrm{Li}$ & $\mathrm{Be}$ & B & $\mathrm{Al}$ & $\mathrm{Si}$ & $\mathrm{V}$ & $\mathrm{Cr}$ \\
\hline 1. $(\mathrm{J})$ & 0.010547 & 0.002416 & 0.000018 & 0.031561 & 0.085516 & 0.001821 & 0.002474 & 0.001483 \\
\hline 2. $(\mathrm{J})$ & 0.008596 & 0.003547 & 0.000035 & 0.070702 & 0.208346 & 0.001186 & 0.002014 & 0.001439 \\
\hline 3. $(\mathrm{J})$ & 0.003099 & 0.003159 & 0.000008 & 0.02546 & 0.031607 & 0.000207 & 0.000968 & 0.000722 \\
\hline 4. $(\mathrm{J})$ & 0.001125 & 0.00314 & 0.00001 & 0.050438 & 0.017054 & 0.000995 & 0.000663 & 0.000753 \\
\hline 5. $(\mathrm{J})$ & 0.004277 & 0.002844 & 0.000009 & 0.024128 & 0.045316 & 0.001532 & 0.001872 & 0.001522 \\
\hline 6. $(\mathrm{J})$ & 0.012135 & 0.003466 & 0.000006 & 0.067138 & 0.028452 & 0.000616 & 0.001936 & 0.001074 \\
\hline 7. $(\mathrm{J})$ & 0.005177 & 0.002801 & 0.000018 & 0.046198 & 0.051148 & 0.000785 & 0.001923 & 0.001234 \\
\hline 8. $(\mathrm{J})$ & 0.001601 & 0.003127 & 0.000002 & 0.039069 & 0.0034 & 0.00069 & 0.000307 & 0.000955 \\
\hline 1. $(\mathrm{S})$ & 0.005806 & 0.003535 & 0.000006 & 0.081338 & 0.007804 & 0.006597 & 0.000842 & 0.002089 \\
\hline 2. $(\mathrm{S})$ & 0.00783 & 0.003043 & 0.000006 & 0.049226 & 0.037147 & 0.003241 & 0.002104 & 0.001197 \\
\hline 3. $(\mathrm{S})$ & 0.005876 & 0.003305 & 0.000004 & 0.08118 & 0.024429 & 0.003233 & 0.000713 & 0.001033 \\
\hline 4. $(\mathrm{S})$ & 0.007128 & 0.003316 & 0.00003 & 0.062023 & 0.068112 & 0.003152 & 0.002129 & 0.00119 \\
\hline 5. $(\mathrm{S})$ & 0.004283 & 0.002996 & 0.000002 & 0.061248 & 0.016757 & 0.002668 & 0.000657 & 0.000766 \\
\hline 6. $(\mathrm{S})$ & 0.006649 & 0.003307 & 0.000024 & 0.054408 & 0.187008 & 0.003027 & 0.002137 & 0.002039 \\
\hline 7. $(\mathrm{S})$ & 0.007319 & 0.003288 & 0.000009 & 0.077949 & 0.038076 & 0.003316 & 0.002026 & 0.001641 \\
\hline 8. (S) & 0.003891 & 0.003994 & 0.000002 & 0.143562 & 0.063514 & 0.004745 & 0.001243 & 0.001549 \\
\hline 9. $(\mathrm{S})$ & 0.007411 & 0.004181 & 0.00001 & 0.071981 & 0.049906 & 0.00486 & 0.001788 & 0.001382 \\
\hline 10. (S) & 0.004138 & 0.00454 & 0.000012 & 0.065237 & 0.010132 & 0.006163 & 0.002727 & 0.001102 \\
\hline Sl. no. & $\mathrm{Mn}$ & $\mathrm{Fe}$ & $\mathrm{Ni}$ & Co & $\mathrm{Zn}$ & As & $\mathrm{Se}$ & $\mathrm{Rb}$ \\
\hline 1. $(\mathrm{J})$ & 0.017457 & 0.129763 & 0.003853 & 0.000223 & 0.049458 & 0.001176 & 0.000137 & 0.001157 \\
\hline 2. $(\mathrm{J})$ & 0.036005 & 0.163471 & 0.004581 & 0.000368 & 0.115186 & 0.00148 & 0.00018 & 0.001409 \\
\hline 3. $(\mathrm{J})$ & 0.007357 & 0.048284 & 0.001427 & 0.000108 & 0.008398 & 0.001329 & 0.000144 & 0.00105 \\
\hline 4. $(\mathrm{J})$ & 0.011206 & 0.05107 & 0.003058 & 0.00014 & 0.017365 & 0.001319 & 0.000171 & 0.001417 \\
\hline $5 .(\mathrm{J})$ & 0.006016 & 0.108942 & 0.003364 & 0.000161 & 0.054281 & 0.001257 & 0 & 0.001478 \\
\hline 6. $(\mathrm{J})$ & 0.026018 & 0.072483 & 0.004164 & 0.000171 & 0.018373 & 0.001599 & 0 & 0.001426 \\
\hline 7. $(\mathrm{J})$ & 0.018356 & 0.06203 & 0.005688 & 0.000259 & 0.019407 & 0.001395 & 0 & 0.001481 \\
\hline 8. (J) & 0.000698 & 0.133878 & 0.003118 & 0.000199 & 0.005232 & 0.000451 & 0.000208 & 0.000523 \\
\hline 1. $(\mathrm{S})$ & 0.001439 & 0.095607 & 0.003801 & 0.000107 & 0.007664 & 0.001409 & 0.000528 & 0.001015 \\
\hline 2. $(\mathrm{S})$ & 0.005351 & 0.082173 & 0.002805 & 0.000123 & 0.025875 & 0.001549 & 0.000373 & 0.001089 \\
\hline 3. $(\mathrm{S})$ & 0.018684 & 0.081234 & 0.002947 & 0.000132 & 0.028322 & 0.00152 & 0.000285 & 0.001235 \\
\hline 4. $(\mathrm{S})$ & 0.024941 & 0.097964 & 0.013255 & 0.000155 & 0.020094 & 0.001872 & 0.000305 & 0.001233 \\
\hline 5. (S) & 0.018225 & 0.07488 & 0.002866 & 0.000131 & 0.015998 & 0.001495 & 0.000122 & 0.001016 \\
\hline 6. (S) & 0.022792 & 0.107884 & 0.02242 & 0.000331 & 0.023867 & 0.001888 & 0 & 0.001144 \\
\hline 7. $(\mathrm{S})$ & 0.035253 & 0.089716 & 0.007979 & 0.000197 & 0.019428 & 0.001705 & 0 & 0.00122 \\
\hline 8. (S) & 0.015853 & 0.131464 & 0.003511 & 0.000348 & 0.013425 & 0.001371 & 0.000309 & 0.001411 \\
\hline 9. $(\mathrm{S})$ & 0.016998 & 0.168828 & 0.00413 & 0.000295 & 0.016909 & 0.001179 & 0.000266 & 0.002178 \\
\hline 10. (S) & 0.001332 & 0.112748 & 0.003207 & 0.000114 & 0.005699 & 0.000947 & 0 & 0.000791 \\
\hline
\end{tabular}


Table 3. (Continued.)

\begin{tabular}{|c|c|c|c|c|c|c|c|}
\hline Sl. no. & $\mathrm{Sr}$ & Mo & $\mathrm{Ag}$ & $\mathrm{Cd}$ & $\mathrm{Sb}$ & $\mathrm{Ba}$ & $\mathrm{Pb}$ \\
\hline 1. $(\mathrm{J})$ & 0.240516 & 0.000366 & 0.000064 & 0.000125 & 0.000104 & 0.014116 & 0.02685 \\
\hline 2. $(\mathrm{J})$ & 0.31093 & 0.0004 & 0.00007 & 0.000168 & 0.000149 & 0.017879 & 0.085029 \\
\hline 3. $(\mathrm{J})$ & 0.289097 & 0.000283 & 0.000126 & 0.000028 & 0.000055 & 0.008385 & 0.000833 \\
\hline 4. $(\mathrm{J})$ & 0.299978 & 0.000449 & 0.000038 & 0.000046 & 0.00008 & 0.0104 & 0.001057 \\
\hline 5. $(\mathrm{J})$ & 0.336426 & 0.000154 & 0.000156 & 0.00008 & 0.000058 & 0.022126 & 0.003609 \\
\hline 6. $(\mathrm{J})$ & 0.355932 & 0.000213 & 0.000043 & 0.000039 & 0.00007 & 0.019209 & 0.001292 \\
\hline 7. $(\mathrm{J})$ & 0.29333 & 0.000282 & 0.000101 & 0.001056 & 0.000086 & 0.01656 & 0.001482 \\
\hline 8. $(\mathrm{J})$ & 0.249764 & 0.000738 & 0.000025 & 0.000016 & 0.000249 & 0.013014 & 0.00006 \\
\hline 1. $(\mathrm{S})$ & 0.333438 & 0.001949 & 0.000035 & 0.000044 & 0.000117 & 0.014517 & 0.000141 \\
\hline 2. $(\mathrm{S})$ & 0.325619 & 0.000304 & 0.000058 & 0.000049 & 0.000087 & 0.019885 & 0.012978 \\
\hline 3. $(\mathrm{S})$ & 0.350658 & 0.000403 & 0.000019 & 0.000072 & 0.000074 & 0.01423 & 0.000716 \\
\hline 4. (S) & 0.383809 & 0.001001 & 0.000071 & 0.000084 & 0.000091 & 0.019293 & 0.002758 \\
\hline 5. (S) & 0.32688 & 0.000303 & 0.000055 & 0.000048 & 0.000067 & 0.01183 & 0.001692 \\
\hline 6. $(\mathrm{S})$ & 0.37535 & 0.00072 & 0.000069 & 0.000116 & 0.000095 & 0.019592 & 0.004854 \\
\hline 7. (S) & 0.374489 & 0.000563 & 0.000033 & 0.000123 & 0.000079 & 0.02143 & 0.003982 \\
\hline 8. (S) & 0.395257 & 0.000433 & 0.000041 & 0.000066 & 0.000081 & 0.015573 & 0.001507 \\
\hline 9. (S) & 0.330537 & 0.000469 & 0.000045 & 0.000129 & 0.000079 & 0.015012 & 0.000658 \\
\hline 10. (S) & 0.369616 & 0.001271 & 0.000033 & 0.000023 & 0.000068 & 0.029814 & 0.000084 \\
\hline
\end{tabular}

Note: Units in $\mathrm{mg} / \mathrm{L}$.

\subsection{Water types}

Using Piper trilinear diagram (figure 4), three main water types were identified: $\mathrm{Ca}-\mathrm{HCO}_{3}, \mathrm{Mg}-\mathrm{HCO}_{3}$ and hybrid. Most of the samples (85\%) are of hybrid type, followed by the $\mathrm{Ca}-\mathrm{HCO}_{3}$ type $(13 \%)$ and the remaining $2 \%$ are of $\mathrm{Mg}-\mathrm{HCO}_{3}$ type. The dominance of hybrid type indicated the role of multiple lithology including carbonates and silicates in controlling the chemistry of the lake water. As discussed above, the catchment of the lake consists of both carbonate rocks (Triassic limestone)

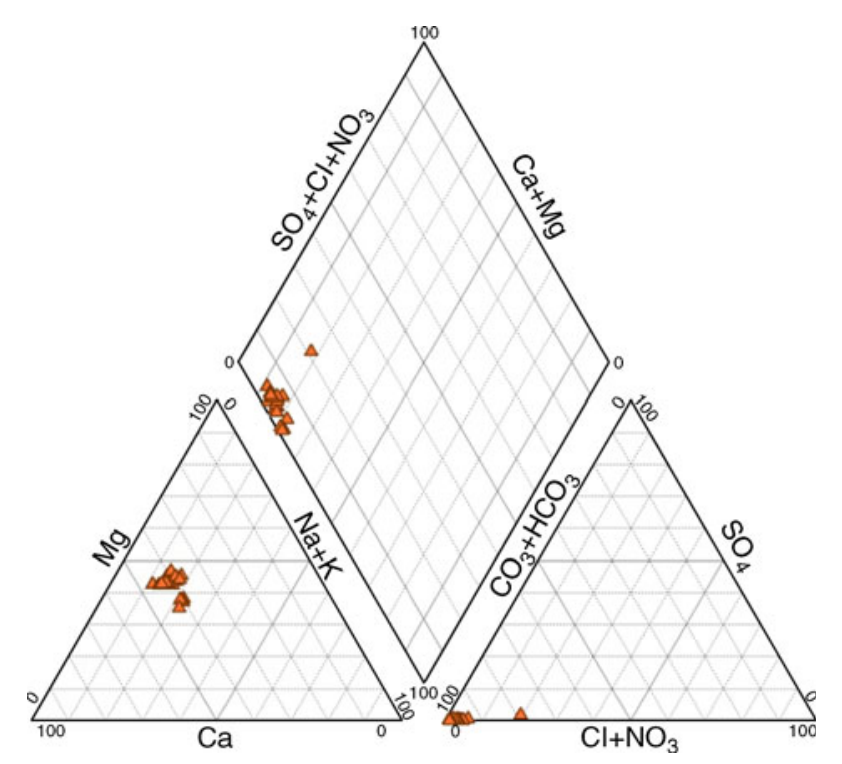

Figure 4. Piper trilinear diagram. and silicates (Karewas deposits), which support the interpretation. The plotting of the water samples near the left corner of the diamond in the Piper trilinear diagram shows that the lake water is rich in $\mathrm{Ca}^{2+}, \mathrm{Mg}^{2+}$ and $\mathrm{HCO}_{3}$ and possesses temporary hardness (Hounslow 1995). This pattern also shows that the lake water is dominated by alkaline earth $\left(\mathrm{Ca}^{2+}, \mathrm{Mg}^{2+}\right)$ and weak acids such as $\mathrm{HCO}_{3}$. No significant seasonal change in the hydrochemical facies was found indicating that the origin of most of the natural ions is lithogenic.

\subsection{Source of the solutes}

Use of Gibbs formula (Gibbs 1970) indicated that the major mechanism controlling the water chemistry of the Manasbal lake is the rock-water interaction (TDS: $122-314 \mathrm{mg} / \mathrm{L}$ and weight ratio of $\mathrm{Na} /(\mathrm{Na}+\mathrm{Ca}):(0.1-0.3)$. To determine the dominant sources (carbonate or silicate rocks) of major ions, $\mathrm{HCO}_{3}$ is plotted against $\mathrm{Ca}, \mathrm{Cl}$ against $\mathrm{Na}, \mathrm{Ca}+\mathrm{Mg}$ against $\mathrm{HCO}_{3}$ and $(\mathrm{Ca}+\mathrm{Mg})$ against $\left(\mathrm{HCO}_{3}+\mathrm{SO}_{4}\right)$ in figure 5. The figure indicates carbonate and dolomite lithology as the dominant source of major ions respectively. The decreased concentrations of $\mathrm{Ca}^{2+}, \mathrm{Mg}^{2+}, \mathrm{Na}^{+}, \mathrm{K}^{+}$and $\mathrm{HCO}_{3}$ in summer and the negative correlation (table 4) between $\mathrm{Ca}^{+}$(June) and $\mathrm{Cl}^{-}$(June), $\mathrm{SO}_{4}^{-}$(June) and $\mathrm{Mg}^{+}$(June), $\mathrm{NO}_{3}$ (September) and $\mathrm{Cl}^{-}$ (September) can be attributed to increased uptake and exchange of these ions by the planktons in summer. The trace elements $\mathrm{Fe}^{2+}, \mathrm{Mn}^{2+}, \mathrm{Ba}^{2+}$ and $\mathrm{Sr}^{2+}$ show higher concentration in the lake water. As $\mathrm{pH}$ and redox conditions influence the 
(a)

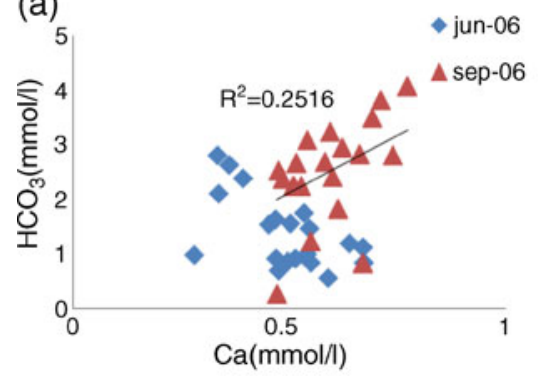

$(\mathrm{c})_{5}$

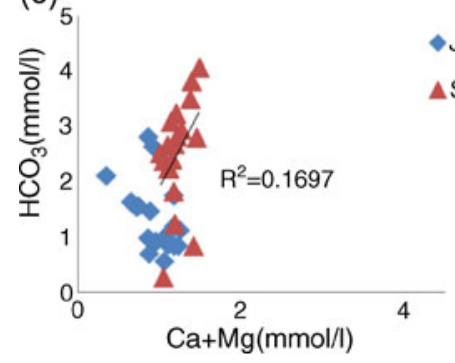

(b)

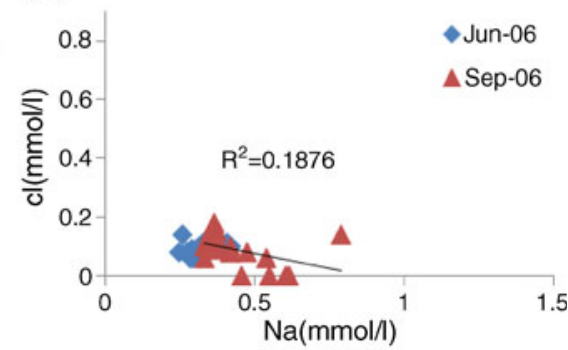

(d)

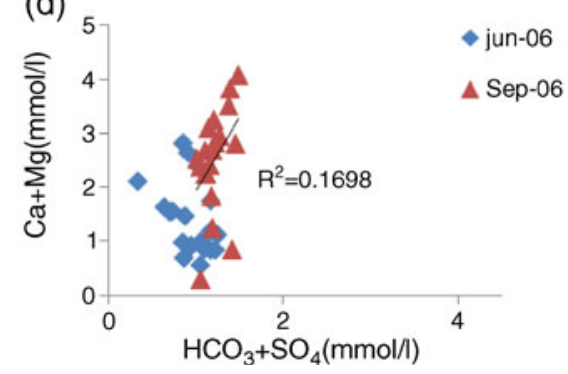

Figure 5. Scatter diagrams showing possible liganding of major ions.

behaviour of various trace elements, the correlation matrix for June (table 5) and September (table 6) was prepared to determine their correlation with each other in different seasons (June and September). It shows that there exists a strong negative correlation between $\mathrm{pH}-\mathrm{Fe}, \mathrm{pH}-\mathrm{Ba}, \mathrm{pH}-\mathrm{Cr}, \mathrm{pH}-$ $\mathrm{Vn}$, and $\mathrm{pH}-\mathrm{Ca}+\mathrm{Mg}$ as well as a positive correlation between $\mathrm{pH}+\mathrm{Mn}, \mathrm{Fe}+\mathrm{Cr}, \mathrm{Mn}+\mathrm{Vn}, \mathrm{Al}+\mathrm{Vn}$, $\mathrm{Al}+\mathrm{Cr}, \mathrm{Al}+\mathrm{Fe}, \mathrm{Ba}+\mathrm{Sr}, \mathrm{Ba}+\mathrm{Cr}, \mathrm{Ba}+\mathrm{Vn}, \mathrm{Cr}+\mathrm{Vn}$ and $\mathrm{Ca}+\mathrm{Mg}$ against $\mathrm{Ba}, \mathrm{Ca}+\mathrm{Mg}$ against $\mathrm{Cr}$ and $\mathrm{Ca}+\mathrm{Mg}$ against $\mathrm{Fe}$. Whereas, in September the $\mathrm{pH}$ of the water samples shows a strong correlation with $\mathrm{Mn}^{2+}$ but negative correlation with $\mathrm{Sr}^{2+}$ and $\mathrm{Ca}+\mathrm{Mg}$. The higher concentration of these trace elements in September shows the reducing environment of lake which facilitates the dissolution of these trace elements. In the oxidizing environment, these trace elements get scavenged and move to sediments responsible for their lower concentration in the lake water in June. The reasons of these temporal variations are connected to the hydrological conditions in the watersheds as well as biological productivity in the lakes. The increased plankton production during summer favours an increased sedimentation of metals bound to particles and a subsequent decrease in the content of most elements in the water column (Salbo and Steinnes 1995). The concentration of $\mathrm{Al}^{2+}$ is low because aluminium is highly insoluble in natural water, and also because of the alkaline water of the lake. The weathering of the $\mathrm{Fe}^{2+}$ - and $\mathrm{Mn}^{2+}$-bearing minerals as well as sewage effluents are the main sources

Table 4. Correlation among different variables (major elements in June and September 2006).

\begin{tabular}{|c|c|c|c|c|c|c|c|c|c|c|c|c|c|c|}
\hline & $\mathrm{Ca}_{-} \mathrm{J}$ & Ca_S & $\mathrm{Na} \_\mathrm{J}$ & $\mathrm{Na} \_\mathrm{S}$ & $\mathrm{Mg}_{-} \mathrm{J}$ & Mg_S & Cl_J & Cl_S & $\mathrm{NO}_{3-} \mathrm{J}$ & $\mathrm{NO}_{3-} \mathrm{S}$ & $\mathrm{SO}_{4-} \mathrm{J}$ & $\mathrm{SO}_{4-} \mathrm{S}$ & $\mathrm{HCO}_{3-} \mathrm{J}$ & $\mathrm{HCO}_{3-\mathrm{S}}$ \\
\hline Ca_J & 1.000 & & & & & & & & & & & & & \\
\hline $\mathrm{Ca} \_\mathrm{S}$ & 0.215 & 1.000 & & & & & & & & & & & & \\
\hline Na_J & -0.264 & -0.237 & 1.000 & & & & & & & & & & & \\
\hline $\mathrm{Na} \_\mathrm{S}$ & 0.279 & 0.441 & 0.045 & 1.000 & & & & & & & & & & \\
\hline Mg_J & 0.235 & -0.523 & 0.135 & 0.168 & 1.000 & & & & & & & & & \\
\hline Mg_S & 0.167 & 0.741 & -0.326 & 0.178 & -0.346 & 1.000 & & & & & & & & \\
\hline Cl_J & -0.774 & -0.337 & 0.391 & -0.168 & -0.098 & -0.581 & 1.000 & & & & & & & \\
\hline Cl_S & 0.135 & 0.206 & -0.452 & -0.433 & -0.216 & 0.377 & -0.458 & 1.000 & & & & & & \\
\hline $\mathrm{NO}_{3}{ }_{-} \mathrm{J}$ & -0.027 & 0.122 & -0.229 & 0.038 & -0.113 & 0.106 & -0.163 & -0.058 & 1.000 & & & & & \\
\hline $\mathrm{NO}_{3}{ }_{-} \mathrm{S}$ & 0.098 & 0.115 & 0.335 & 0.480 & 0.127 & -0.338 & 0.367 & -0.782 & -0.039 & 1.000 & & & & \\
\hline $\mathrm{SO}_{4-} \mathrm{J}$ & 0.052 & 0.586 & -0.362 & 0.168 & -0.755 & 0.601 & -0.264 & 0.215 & 0.169 & -0.233 & 1.000 & & & \\
\hline $\mathrm{SO}_{4-} \mathrm{S}$ & -0.418 & -0.008 & 0.024 & -0.465 & -0.289 & 0.254 & 0.363 & 0.077 & -0.318 & -0.174 & 0.261 & 1.000 & & \\
\hline $\mathrm{HCO}_{3-\mathrm{J}}$ & -0.579 & -0.312 & 0.327 & -0.588 & -0.149 & -0.147 & 0.325 & 0.207 & -0.235 & -0.360 & -0.139 & 0.261 & 1.000 & \\
\hline $\mathrm{HCO}_{3-} \mathrm{S}$ & -0.240 & 0.510 & -0.370 & -0.214 & -0.688 & 0.197 & 0.066 & 0.533 & 0.171 & -0.189 & 0.344 & -0.043 & 0.212 & 1.000 \\
\hline
\end{tabular}


Table 5. Correlation matrix of trace elements in June 2006.

\begin{tabular}{|c|c|c|c|c|c|c|c|c|c|}
\hline & $\mathrm{pH}$ & $\mathrm{Fe}$ & Mn & $\mathrm{Ba}$ & $\mathrm{Sr}$ & $\mathrm{Cr}$ & $\mathrm{Vn}$ & $\mathrm{AL}$ & $\mathrm{Ca}+\mathrm{Mg}$ \\
\hline $\mathrm{pH}$ & 1.000 & & & & & & & & \\
\hline $\mathrm{Fe}$ & -0.653 & 1.000 & & & & & & & \\
\hline Mn & -0.342 & 0.383 & 1.000 & & & & & & \\
\hline $\mathrm{Ba}$ & -0.663 & 0.392 & 0.374 & 1.000 & & & & & \\
\hline $\mathrm{Sr}$ & 0.028 & -0.273 & 0.298 & 0.591 & 1.000 & & & & \\
\hline $\mathrm{Cr}$ & -0.747 & 0.645 & 0.359 & 0.778 & 0.068 & 1.000 & & & \\
\hline $\mathrm{Vn}$ & -0.562 & 0.273 & 0.568 & 0.635 & 0.252 & 0.815 & 1.000 & & \\
\hline $\mathrm{AL}$ & -0.381 & 0.646 & 0.780 & 0.310 & 0.055 & 0.559 & 0.553 & 1.000 & \\
\hline $\mathrm{Ca}+\mathrm{Mg}$ & -0.912 & 0.729 & 0.154 & 0.597 & -0.001 & 0.634 & 0.338 & 0.316 & 1.000 \\
\hline
\end{tabular}

Table 6. Correlation matrix of trace elements in September 2006.

\begin{tabular}{|c|c|c|c|c|c|c|c|c|c|}
\hline & $\mathrm{pH}$ & $\mathrm{Fe}$ & $\mathrm{Mn}$ & $\mathrm{Ba}$ & $\mathrm{Sr}$ & $\mathrm{Cr}$ & $\mathrm{Vn}$ & $\mathrm{Al}$ & $\mathrm{Ca}+\mathrm{Mg}$ \\
\hline $\mathrm{pH}$ & 1.000 & & & & & & & & \\
\hline $\mathrm{Fe}$ & -0.008 & 1.000 & & & & & & & \\
\hline $\mathrm{Mn}$ & 0.690 & -0.385 & 1.000 & & & & & & \\
\hline $\mathrm{Ba}$ & -0.025 & 0.035 & 0.170 & 1.000 & & & & & \\
\hline $\mathrm{Sr}$ & -0.512 & 0.152 & -0.191 & 0.406 & 1.000 & & & & \\
\hline $\mathrm{Cr}$ & -0.107 & 0.246 & -0.072 & 0.044 & 0.250 & 1.000 & & & \\
\hline Vn & 0.266 & 0.261 & 0.333 & 0.879 & 0.373 & 0.110 & 1.000 & & \\
\hline $\mathrm{Al}$ & 0.257 & 0.209 & 0.067 & 0.050 & 0.435 & 0.480 & 0.317 & 1.000 & \\
\hline $\mathrm{Ca}+\mathrm{Mg}$ & -0.595 & 0.513 & -0.575 & 0.309 & 0.254 & 0.379 & 0.124 & -0.243 & 1.000 \\
\hline
\end{tabular}

of $\mathrm{Fe}^{2+}$ and $\mathrm{Mn}^{2+}$ in the lake water. $\mathrm{Mn}^{2+}$ is likely to be related from minerals along with $\mathrm{Fe}^{2+}$ and $\mathrm{Ca}^{2+} \cdot \mathrm{Sr}^{2+}$ and $\mathrm{Ba}^{2+}$ belong to the same group and may have similar characters. However, $\mathrm{Be}(\mathrm{OH})_{2}$ is almost insoluble, whereas $\mathrm{Sr}(\mathrm{OH})_{2}$ and $\mathrm{Ba}(\mathrm{OH})_{2}$ are sparingly soluble. $\mathrm{Sr}^{2+}$ and $\mathrm{Ba}^{2+}$ exist in nature as sulphates or carbonates, which have very limited solubility in water (Liptrot 1989). The relative concentrations of these elements in groundwater are controlled by the solubility of their sources. The oxides of $\mathrm{Sr}$ and $\mathrm{Ba}$ react with water to form strong bases (Mahan 1966). Theses oxides also react with acids and dissolve in water to give stable $\mathrm{Sr}^{2+}$ and $\mathrm{Ba}^{2+}$ ions which could be leached from the host rock and other minerals into the groundwater. Strontium is strongly coupled to calcium in primary source rocks and is mostly abundant in Ca-rich sources such as limestone. $\mathrm{Sr}^{2+}$ occurs primarily in dolomites and limestone. The plots of $(\mathrm{Ca}+\mathrm{Mg})$ against $\mathrm{HCO}_{3}$ and $(\mathrm{Ca}+\mathrm{Mg})$ versus $\left(\mathrm{HCO}_{3}+\mathrm{SO}_{4}\right)$ (figure 5) suggest dolomite lithology as the main source of major ions.

\subsection{Anthropogenic inputs into the lake water system}

Nitrate is an important pollutant in the environment, being generally derived from the agricultural fertilizers, atmospheric input, human and animal excreta, bio-combustion, etc. (Prospero and
Savoie 1989; Agarwal et al 1999; Jeong 2001; Xiao and Liu 2002; Liu et al 2006). The distribution trend of $\mathrm{NO}_{3}$ in the Manasbal lake clearly indicates anthropogenic inputs. Higher concentrations are observed near the periphery towards eastern side of the lake with more anthropogenic activities. The concentration of $\mathrm{NO}_{3}$ was $0.01-2 \mathrm{mg} / \mathrm{L}$ in winter and comparatively lower $(0.002-0.9 \mathrm{mg} / \mathrm{L})$ in summer (figure 6). The higher $\mathrm{NO}_{3}$ concentration along the shore reflects the pollution due to human and animal excreta. The desirable limit of nitrate in drinking water is $45 \mathrm{mg} / \mathrm{L}$ according to WHO norms. Higher concentration of nitrate in drinking water makes it toxic and causes blue baby disease methaemoglobinaemia in children and gastric carcinomas. However, regarding $\mathrm{NO}_{3}$ contamination $(1.72-2 \mathrm{mg} / \mathrm{L})$, although the values are within the permissible limit and not very alarming, the gradually increasing trend is certainly not acceptable. It is however, important to guard its spatio-temporal variability as the water is used for domestic as well as agricultural purposes.

\section{Water quality of the lake}

A major objective of the study of the hydrochemistry of the Manasbal lake was to find out whether the lake water is fit for drinking, irrigation and other purposes (Todd 1980; Chow et al 1988). The 

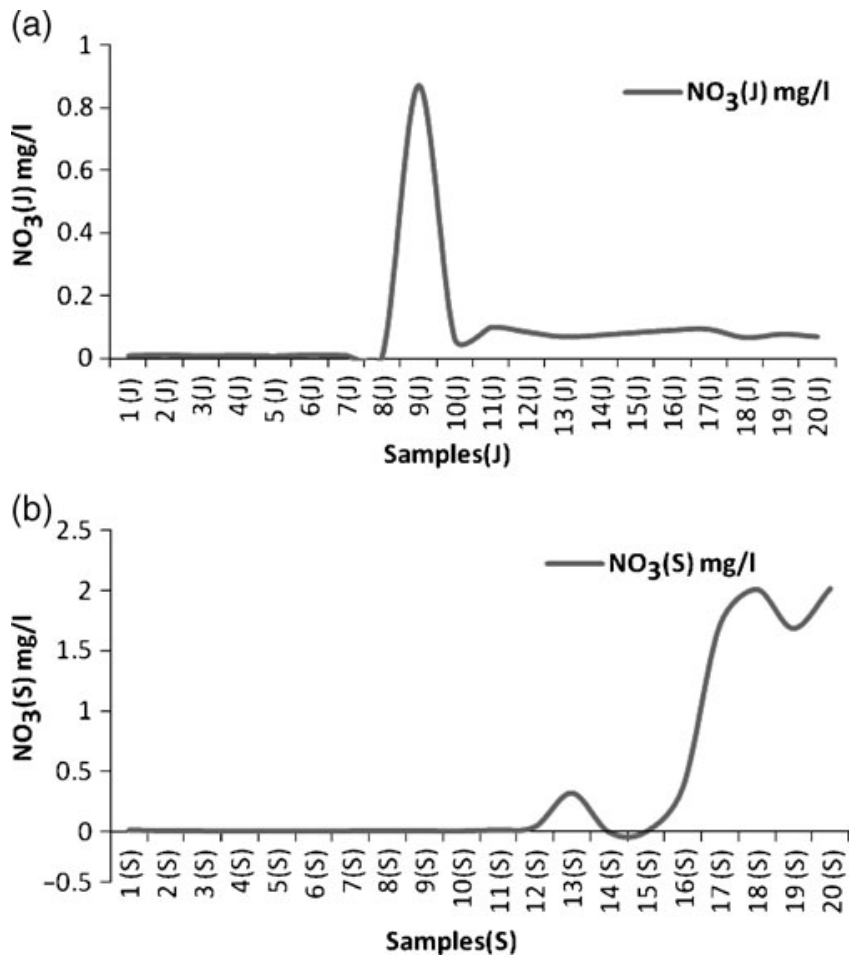

Figure 6. Showing nitrate trend in (a) June 2006 and (b) September 2006.

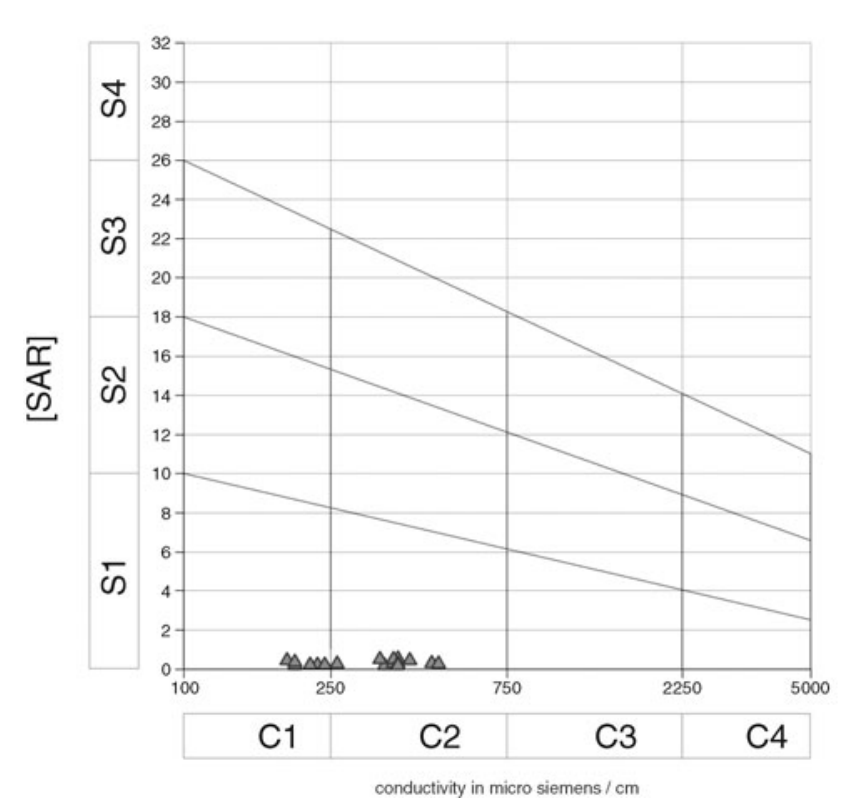

Figure 7. Salinity hazard diagram.

quality of the lake water with respect to major ion chemistry and trace elements is safe for drinking purposes according to the guidelines proposed by WHO (1998). The relative activity of sodium ion in the exchange reaction with soil is expressed in terms of a ratio known as sodium adsorption ratio
(SAR). The Salinity Laboratory of the US Department of Agriculture recommends SAR because of its direct relation to the adsorption of sodium by soil. The salinity hazard diagram (figure 7) was used for the classification of water samples at various sites from Manasbal lake to study its suitability for irrigation. The diagram shows that water samples of eight sites are from the C2S1 field and possess medium salinity and low sodium hazards. Therefore, the water from those sites can be considered suitable for plants with moderate salt tolerance and can be used for irrigation. Further, $50 \%$ of samples from the lake water (approx. 8) are from the C1S1 field of the diagram, possess low sodium and low salinity hazards which indicates that water from these sites does not pose any threat to vegetation, crops and soil. Hence, the water of the study area can be considered suitable for irrigation. The crop growth is very high and the plant growth is very good in these soils.

\section{Conclusions}

The primary data were generated using the chemical analyses of the water samples and the data scarcity was overcome by making precise estimates at additional locations using the theory of regionalized variables. The lake water was found to be alkaline with low total dissolved salts. Calcium was the dominant cation and bicarbonate, the dominant anion. Three types of water found in the lake $\left(\mathrm{Ca}-\mathrm{HCO}_{3}, \mathrm{Mg}-\mathrm{HCO}_{3}\right.$ and hybrid water $)$, reflect the initial stage of evolution of the lake water. Significant temporal variation was found in the trace elements $\mathrm{Fe}^{2+}, \mathrm{Mn}^{2+}, \mathrm{Ba}^{2+}$ and $\mathrm{Sr}^{2+}$, which may be due to the hydrological conditions in the watershed as well as biological productivity in the lake. The sources of solutes were found to be lithogenic with carbonate (Triassic Limestone) and silicate (Karewas) as the dominant sources of solutes. All the chemical constituents were found to be within the WHO permissible limits indicating that the lake water is potable and suitable for other purposes. Linear geostatistics could successfully be applied to enhance the dataset using the continuity of the lake water and the absence of turbulence found in major fast flowing rivers. However, regular monitoring using an optimal monitoring network at a suitable frequency is recommended to detect any unacceptable variability of pollutants and adopt appropriate remedial measures.

\section{Acknowledgements}

The authors are grateful to Director, NGRI (CSIR), Hyderabad for his kind permission to 
publish this paper and encouragement for carrying out the research. The first author acknowledges the University of Kashmir for the support in data collection.

\section{References}

Agarwal G D 1999 Integrated management of water quality. The role of agricultural diffuse pollution sources; Water Sci. Tech. 39 33-47.

Ahmed S and Gupta C P 1989 Stochastic spatial prediction of hydrogeologic parameters: Use of cross validation in krigings; In: Proc. International Groundwater Workshop: IGW89, Hyderabad, India. Feb-March 1989, (eds) Gupta et al, Oxford and IBH Publications Co., 3 77-90.

APHA 1995 Standard methods for the examination of water and waste water; 19th edn., American Public Health Association, Washington DC.

Berner E K and Berner R 1987 The Global Water Cycle: Geochemistry and Environment (New Jersey: Prentice-Hall), 397p.

Bhat D K 1989 Geology of Karewas basin, Kashmir; Geol. Surv. India Rec. 122p.

Bhatt S 2004 Proceedings of the National Conference on Kashmir, Ecology \& Environment: New concerns \& strategies; In: Major environmental issues in Kashmir (ed.) Bhatt S, APH Publishing Corporation, New Delhi, 91-98.

Chow V T, Maidment, David R and Mays L W 1988 Applied Hydrology (UK: McGraw-Hill Science Engineering), 572p.

Fetter C W 1980 Applied Hydrogeology (Columbus: Merill Publication Corporation), 592p.

Hamilton D P and Schaldow S G 1997 Prediction of water quality in lakes and reservoirs. Part I - Model description; Ecol. Model. 96 91-110.

Hounslow W A 1995 Water Quality Data Analysis and Interpretation (USA: Lewis Publishers), 381p.

Hussain M 1998 Geography of Jammu and Kashmir (New Delhi: Rajesh Publications), 38p.

Gibbs R J 1970 Mechanism controlling world water chemistry; Science 170 1088-1090.

Jeong C H 2001 Effects of landuse and urbanization on hydrochemistry on contamination of groundwater Tarjon area Kore; J. Hydrol. 253 194-210.

Journal A and Huijbirgts Ch 1978 Mining Geostatistics (London: Acadaemic Press), 478p.

Karanth K R 1987 Groundwater Assessment Development and Management (New Delhi: Tata McGraw-Hill), 448p.

Kapoor A N and Das A G 1997 Principles of Physical Geography (New Delhi: S Chand and Company Ltd.).

Keller E A 1985 Environmental Geology (New Jersey: Prentice Hall Publications).
Khan A R, Ganai A R and Bhat S A 2006 Geography of India and Kashmir (Srinagar: City Book Centre).

Krishnan M S 1968 Geology of India and Burma (Madras: Higging Thans Ltd.).

Lawrence W T 1895 The Valley of Kashmir (London: Asian Educational Services), pp. 40-42.

Liptrot G F 1989 Modern Inorganic Chemistry, 4th edn. (Musselburgh: Scoltprint).

Liu C Q, Li S L, Lang Y C and Xiao H Y 2006 Using $\delta^{15} \mathrm{~N}$ - and $\delta^{18} \mathrm{O}$-values to identify nitrate sources in karst ground water, Guiyang, Southwest China; Environ. Sci. Technol. 40 6928-6933.

Mahan B H 1966 College Chemistry (Reading, Massachusetts: Addison Wesley Publishing Company).

Marsily G de and Ahmed S 1987 Application of kriging techniques in groundwater hydrology; Invited paper, J. Geol. Soc. India 29(1) 47-69.

Matheron G 1971 The Theory of Regionalized Variables and its Applications, Translation 1971 (France: Ecole des Mines de Paris).

Prospero J M and Savoie D L 1989 Effect of continental sources on nitrate concentration over the Pacific Ocean; Nature 339 687-689.

Raina A N 1971 Geography of Jammu and Kashmir (Jammu: Radha Krishan Anand \& Co.).

Raza M, Ahmad A and Mohammad A 1978 The Valley of Kashmir, a Geographical Interpretation (New Delhi: Vikas Publication House).

Salbo B and Steinnes E 1995 Trace Elements in Natural Waters (Boca Raton: CRC Press).

Scalf M R, McNabb J F, James F and Willaim J 1987 Manual of Groundwater Sampling Procedures (Jodhpur: Scientific Publishers).

Sharma S K and Bakshi S R 1996 Encyclopedia of Kashmir (New Delhi: Annual Publications Pvt. Ltd.).

Subramanium V 2000 Water Quantity and Quality Perspective in South Asia (England: Kingston International Publishers), 1-13.

Tebbutt T H Y 1998 Principles of Water Quality Control (Oxford, UK: Butterworth-Heinemann).

Todd D K 1980 Ground Water Hydrology (New York: John Wiley \& Sons).

Wadia D N 1975 Geology of India (New Delhi: Tata McGraw Hill Publishing Co.).

WHO 1998 Guidelines for drinking water quality, addendum, survelliance and community supplies, 2nd edn., Vol 3, WHO, Geneva.

Xiao H Y and Liu C-Q 2002 Sources of nitrogen and sulfur in wet deposition at Guiyang, southwest China; Atmos. Environ. 36 5121-5130.

Yousuf A R 1992 Biotic Communities and their role in the tropic conditions in Kashmir Himalayan Lakes, Technical Report submitted by the University of Kashmir, CSIR Research Project. 